Article

\title{
The Construction of an Intelligent Risk-Prevention System for Marine Silk Road
}

\author{
Xingqun Xue ${ }^{1}$, Xiaochen Ma ${ }^{1}$, Mingnan Jiang ${ }^{1}$, Yang Gao ${ }^{1, *}$ and Sae Woon Park ${ }^{2}$ \\ 1 School of Business, Dalian University of Technology, Panjin 124221, China; xxq@dlut.edu.cn (X.X.); \\ Ma_xiaochen_dut@163.com (X.M.); jmnmingn@163.com (M.J.) \\ 2 Department of Business Administration, Changwon National University, Changwon 51140, Korea; \\ assw@changwon.ac.kr \\ * Correspondence: gzm@dlut.edu.cn
}

Received: 19 June 2020; Accepted: 20 July 2020; Published: 22 July 2020

\begin{abstract}
The purpose of this study is to explore how to effectively prevent risks in the Marine Silk Road. This paper establishes a hierarchical theoretical framework by using the interpretive structural modeling (ISM) and explores an application system for intelligent prevention. The fuzzy set theory is also used to screen out the unnecessary attributes, and a decision-making and trial evaluation laboratory (DEMATEL) is proposed to manage the complex interrelationships among the aspects and attributes. Finally, we suggest an applicable risk-prevention system for the Marine Silk Road. Our results: (1) the solution to international political and trade risks is the most critical for the risk prevention; (2) the solution to marine meteorological risks relies mainly on the improvement of ocean information sharing mechanism driven by big data which needs international cooperation in terms of information and technology; (3) the solution to marine energy and environmental risks also requires active international cooperation; (4) the application system should be built based on three levels, including the international level, the government level, and the company level. This theoretical hierarchical framework aims to guide the countries alongside the road to effectively prevent the risks on the Marine Silk Road, promote the sustainable development of the Marine Silk Road, and develop the transnational economies and cultures.
\end{abstract}

Keywords: Marine Silk Road; sustainable development; intelligent risk-prevention system; Fuzzy-DEMATEL-ISM

\section{Introduction}

"One Belt and One Road" which originated in China, is the one of longest economic corridors and the most promising economic cooperation zones in the world. In October 2013, China first proposed the initiative of jointly building the 21st century "Marine Silk Road" [1]. The Marine Silk Road will be of great and far-reaching significance, for it will enhance international cooperation, promoting common economic development, friendship, and cultural exchanges among the people from different cultural traditions, by building a marine shipping network composed of ports and routes and establishing communication channels among the countries along the route [2].

The Marine Silk Road refers to the marine section of the historic Silk Road that linked China, Southeast Asia, Indian subcontinent, Arabian Peninsula, Somalia, Egypt, and the European subcontinent. From 2001 to 2015, China's trade with the countries along the belt and road has grown from US \$8.4 billion to US \$112 billion, of which China's trade with 11 countries in the Southeast Asia has reached US $\$ 48.03$ billion. The cooperation of the countries in regard to marine-cultural, marine engineering technology, and marine tourism will contribute to the countries' economic development [3]. 
However, the development of the Marine Silk Road will also bring about a certain potential challenges and risks to the countries involved [1], such as the risk of meteorological disaster [4], the risk of the international cultural conflict [5], and the economic and social risk led by national policies [6], etc. Therefore, in order to escort the sustainable development of the Marine Silk Road and promote economic and cultural development of the countries along the route, it is necessary to accurately identify, assess and effectively prevent the risks it may face. Liu focused on the assessment and early warning of marine traffic safety risks under severe weather such as storms and high waves [7]. Most of the researches on risk assessment have been carried out on the social and economic disaster bodies in small regions [8]. Some scholars have conducted researches on emergency measures after disasters, such as grouping and ranking the rescue needs of different regions [9]. Fan et al. focus on typical risks in different regions such as Southeast Asia, South Asia and Africa [10]. Ross studied the cultural conflicts in the development of the "Belt and Road" [5].

However, most of the existing studies focus on the risk of the Marine Silk Road only in specific aspects. In addition, there is no in-depth analysis of the internal connection of various prevention methods, and there is also a lack of a systematically integrating framework to provide guidance toward the intelligent prevention of the risks involved in Marine Silk Road. Therefore, it is necessary to conduct researches aimed at providing a reliable risk prevention system to promote the development and smooth setout of the Marine Silk Road.

In this context, this study which intends to develop an intelligent risk-prevention system for the Marine Silk Road will contribute to both literature and practice. To do so, we follow three steps in our analysis. First, we establish a theoretical framework of systematic prevention system against various risks which the Marine Silk Road may face, sort out the risks systematically and identify the potential risks of the Marine Silk Road accurately. Second, a multilevel decision model which combines Fuzzy set theory, a decision test and evaluation laboratory (DEMATEL), and an explanatory structure model (ISM) is established to evaluate the performance and relationship of various prevention methods. Third, based on the results of the first two steps above, an operational and feasible intelligent risk prevention system is established and guidance is provided for the sustainable development of the Marine Silk Road.

Based on the empirical results, we try to draw conclusions from the following four perspectives. First, the risks involved in the development of the Marine Silk Road can be determined in five dimensions: the risk of disastrous climate, the risk of marine environmental pollution, safety risk of marine traffic, economic and financial risk, and social and political risk. Second, there can be a variety of prevention methods for these five types of risks, which are different in terms of method, mechanisms, and degrees of their effects. It is necessary for a risk-prevention system to cover all these differences. Third, the study found that these risk-prevention methods can be divided into five different levels. Addressing social and political risks is the first step in preventing risks along the Marine Silk Road. Then, political risks and international trade security risks should be prevented while ensuring a stable international environment. After that, the marine monitoring through big data technology and the green development of marine energy can be realized. Fourth, an application system combining the stakeholder theory is established for risk prevention of the Marine Silk Road, which will be built based on three levels: the international level, the government level, and the company level. The research results can provide an important theoretical reference for the sustainable development of the Marine Silk Road.

\section{Literature Review}

With the development of the Marine Silk Road in recent years, the countries involved have become more closely related, which makes the issue of Marine risks a more significant and far-reaching one. It has become necessary for those countries to cooperate more closely to cope with common issues such as preventing or minimizing the risks. 
This section provides a systemic review of the literature, including the theoretical background, the possible risks of the development of the Marine Silk Road, and the prevention methods proposed. The list of countries located on Marine Silk Road is shown in Table 1. By reviewing the existing literature, this study classifies the risks into categories: risk of catastrophic oceanic climate, risk of pollution to the marine environment, risk of marine traffic, economic and financial risk, and sociopolitical risk.

Table 1. List of countries alongside the Maritime Silk Road.

\begin{tabular}{|c|c|}
\hline Area & Country \\
\hline Africa & $\begin{array}{l}\text { Egypt, Sudan, Libya, Algeria, Tunisia, Morocco, Kenya, Somalia, Eritrea, } \\
\text { Djibouti, Tanzania }\end{array}$ \\
\hline Europe & $\begin{array}{l}\text { Germany, France, Italy, Netherlands, Luxembourg, Belgium, United Kingdom, } \\
\text { Denmark, Ireland, Greece, Cyprus, Hungary, Malta, Spain, Portugal, Sweden, } \\
\text { Finland, Austria, Czech Republic, Estonia, Latvia, Lithuania, Poland, Slovakia, } \\
\text { Slovenia, Bulgaria, Romania, Croatia, Bosnia, Hercegovina, Montenegro, Serbia, } \\
\text { Albania, Macedonia }\end{array}$ \\
\hline Oceania & Australia, New Zealand \\
\hline South Asia & Pakistan, Bangladesh, Sri Lanka, India, Maldives \\
\hline South Pacific & Fiji, Cook Islands, Micronesia, Niue, Samoa, Tonga, Tuvalu, Papua New Guinea \\
\hline Southeast Asia & $\begin{array}{l}\text { Philippines, Brunei, Cambodia, Indonesia, Laos, Malaysia, Myanmar, } \\
\text { Singapore, Thailand, Vietnam }\end{array}$ \\
\hline West Asia & $\begin{array}{l}\text { Turkey, Jordan, Lebanon, Israel, Palestine, Yemen, United Arab Emirates, Saudi } \\
\text { Arabia, Oman, Qatar, Kuwait, Bahrain, Iran, Iraq, Syrian Arab Republic }\end{array}$ \\
\hline
\end{tabular}

\subsection{Risk of Catastrophic Oceanic Climate}

As a result of the global warming, sea levels and the temperature are rising, and at the same time the frequency and severity of various marine disasters continue to increase. The Marine Silk Road is often affected by disasters like storm surges [11]. Of all those disasters, the historical tsunamis in the Indian Ocean and the Mediterranean Sea account for about $21 \%$ of the global total [11]. These catastrophic marine climate risks will seriously affect the safety of marine traffic and transportation and hinder the sustainable development of the Marine Silk Road.

\subsubsection{Build an Intelligent Warning System for Disasters}

In recent years, a program called the Southeast Asian ocean observing system has greatly promoted the cooperation of the countries along the Marine Silk Road in marine forecasting and monitoring. Andaman Sea quasi real-time floating, latent standard observation arrays has been formed [7], which can strengthen the capabilities of monitoring, predicting, and early warning of the oceanic climate. Establishing more tide stations and using the satellite monitoring information system will also be of great importance in monitoring and preventing natural disasters [11]. These latent standard observation arrays cannot only directly support marine forecasting system, but also provide important observation data for the study of the climate and the marine ecological protection.

\subsubsection{Build an Intelligent Information Sharing Platform for Disasters}

Currently, most countries along the "21st century Marine Silk Road" have multiple problems such as underdeveloped economy, retarded technology, unbalanced development, and backward management level [12]. However, the establishment of marine information sharing mechanism, along with the rapid development of information technology and the increasingly frequent and close economic exchanges between countries, enables countries alongside the road to effectively avoid the risk of international marine disasters [11] which they might not be able to effectively deal with for themselves, share a disaster database for further analyses, and provide a systemic understanding of the 
regional disaster frequency, intensity, and location [12], so that the international aid can be provided in time and the secondary or subsequent disasters can be avoided.

\subsubsection{Training Professionals and Technical Personnel in Marine Meteorology}

Marine professionals can capture and analyze marine climate information effectively and reasonably, give early warnings of marine natural disasters, and help countries be prepared for them. The technical advantages of training marine professionals can contribute to the scientific and technological progress of a marine disaster prevention system and the formulation of international rules [13]. Marine meteorological professionals can not only participate in major international organizations for marine security, but also share their expertise in marine disasters with the society and thus promote the improvement of the level of international marine emergency management [14].

\subsection{Risk of Pollution to the Marine Environment}

Marine pollution is also one of the contemporary marine problems. Emma argues that marine pollution is a growing environmental concern worldwide, endangering numerous marine species [15]. Marine environmental crises arise when plastic wastes from land and fuel leaks from ships pollute marine water. To solve these problems, countries along the Marine Silk Road are in need of more resources and cooperation with other countries.

\subsubsection{Accelerate the Development of Clean Energy for Ships}

Marine pollution sometimes occurs by accident with the leakage of toxic and harmful substances from ships carrying them during the voyage. An accidental oil spill can also cause pollution in marine ecological environment. The negligence of the management regarding the accidental offshore oil spill has brought about heavy disasters to marine ecological environment as well as human beings [16]. As the new wave, marked by information technology, has been booming, it has prompted the development of the shipping industry [17]. The development of IT and clean energy technology are reducing consumption of fossil fuel for ships, thus reducing carbon dioxide emissions. The integrated garbage management systems for ships may also contribute to environmental protection.

\subsubsection{Build Natural Barriers for Marine Life}

It has been reported that there are more than 200 kinds of microorganisms capable of degrading oil, which belong to more than 70 genera, of which bacteria account for about 40 genera and dominate the marine ecosystem [18]. Investment in marine ecosystems can prevent or mitigate the damage caused by coastal and marine natural disasters. Moreover, coastal fortifications can also be built through marine ecosystems [19]. For example, reed and mangrove wetland ecosystems, which have good tolerance to nutrient enrichment and eutrophication, and are mostly in a state of nutrient deficiency, can filter and absorb nutrients from sewage and play a positive role in improving the marine ecological environment [20].

\subsubsection{Promote the Development of Smart Marine Pollution Monitoring and Control Technology}

The application of high and new technologies in the development of new instruments for marine environment detection is mainly reflected in two aspects, namely aquatic detection technology and satellite remote sensing and telemetry technology [21]. Regular monitoring of severe oil pollution in the gulf is carried out by using low-cost satellite monitoring methods, and oil pollution is identified and tracked using products retrieved from satellite images to intervene and minimize its impact. It is of great significance for the development of marine pollution and ecological environment monitoring technology to develop sensors suitable for pollution and ecological environment monitoring or micro-instruments for on-site automatic monitoring by comprehensive application of physical, chemical, and biological technologies [22]. 


\subsubsection{Intelligent Optimization of Marine Pollution Control Methods}

The intelligent treatment of marine pollution generated by sea transportation can reduce the treatment cost of pollution as far as possible, improve the treatment efficiency, and shorten the treatment time. Countries can learn from each other's advanced experience in marine waste recycling treatment, actively encourage the public to participate in technological innovation, increase investment in science and technology, introduce advanced marine environmental and ecological restoration technologies from regions or countries, and improve resource conversion capacity [22].

\subsection{Risks of Marine Traffic}

With the development of the Marine Silk Road, marine transport is playing an increasingly important role. Marine traffic risk refers to the risk of improper operation or collision between ships or between ships and ports during navigation. Therefore, marine traffic safety management is also facing great pressure. Hu analyzed the hazards and accident characteristics of coastal waters, obtained the distribution structure of marine traffic safety risks, and proposed some risk control methods [23].

\subsubsection{Promote the Intelligent Ship}

The occurrence of many marine traffic accidents is related to ship factors to varying degrees. Ship factors include ship size, ship age, ship structure, ship equipment, and many other aspects [24]. The intelligent ship may be realized via machinery monitoring and control system, which is the automation solution for medium and to large size ships. The intelligent ship improves the efficiency and productivity of ship staff and ensures the safety of navigation by increasing the quality of controlling and handling ship. The introduction of the intelligent transportation infrastructure is one of the important measures to improve the efficiency of transportation $[17,25]$.

\subsubsection{Use Big Data Technology to Monitor Ocean Passages}

Under the background of big data, the use of AIS (automatic identification system) data, through the statistical analysis of ship collision, can effectively avoid the busiest waterways at high risk of the collision [26]. AIS is an automatic tracking system that uses transponder on vessels and is used by vessel traffic services [27]. AIS information supplements marine radar, which continues to be an important method of collision avoidance for sea transportation.

\subsubsection{Standardized and Automated Ship Navigation Operation}

Marine practitioners have uneven professional quality and safety awareness, and frequent unreasonable passage phenomenon, which is one of the important factors causing ship accidents [24] It is estimated that more than $50 \%$ of potential accidents are caused by human error, most of which are caused by inattention. Therefore, improving deck crew's ability to deal with emergencies caused by autopilot failure is also a potential way to improve automatic monitoring [28]. Standardized ship navigation can actively reduce the incidence of marine traffic accidents.

\subsubsection{Promote the Development of Smart Ports}

Port investment in prevention for coastal and marine disaster remains a challenging decision with major implications. It is of far-reaching significance for the sustainable development of the Marine Silk Road [19]. However, the current port construction research based on the unique geographical and technical characteristics of the sea areas along the Marine Silk Road is not enough, and there is a lack of targeted service products for ship navigation and port operations [12]. It is of great significance to increase the operation efficiency of the international shipping industry and eliminate the bottleneck constraints by increasing the deep-water port work [17]. 


\subsection{Economic and Financial Risks}

Due to the differences in systems, habits, customs between countries, international economic and trade conflicts are inevitable [29]. The development of the Marine Silk Road makes countries involved more closely connected economically with each other, so countries involved are more vulnerable to the impact of exchange rate fluctuations and trade disputes are likely to arise. In addition, the continuous increase of international trade and foreign direct investment has exposed them to international fraud and overseas investment risks, which have a negative impact on the stable development of their economies and the enhancement of international economic cooperation, thus posing a major challenge to the development of the Marine Silk Road [30].

\subsubsection{Improve the International Trade Finance System}

In recent years, fraud still exists in international trade. Bac and Raff analyzed the feasibility of inter-state coordination and compromise to solve international trade frictions [31]. The advent of block chain technology is on the verge of revolutionizing trade finance. By using block chain technology, the risk of international trade fraud could be reduced [32]. In addition, strengthening the construction of the goods trade and management system, as well as simplifying and coordinating international trade procedures also play a positive role in removing barriers to international trade [33]. A further reduction of tariffs and easing of non-tariff barriers will help to improve trade facilitation and increase international trade.

\subsubsection{Promote the Development of Financial Derivatives}

In addition to the flow of people, the Marine Silk Road is also accompanied by the flow of funds, involving capital flow, especially international direct investment, indirect investment and international credit, which all affect the economy of the countries involved [33]. Enterprises can usually prevent exchange rate risks through matching leads or lags of payment [34]. On the other hand, the exchange rate risks are hedged by trading options, futures, and other financial derivatives [35].

\subsubsection{Establish an Investment Risk Assessment System}

The establishment of a national risk assessment system, such as the regular release of overseas investment risk reports, the continuous improvement of overseas investment information databases, the regular release of risk assessment reports, and the risk warning mechanism can assist enterprises to reduce the risk of overseas investment [1]. The innovation of financial derivatives plays an important role in improving the risk management system of each country's shipping industry and ensuring the stable development of each country in international competition [36].

\subsubsection{Establish and Improve the Insurance System}

International trade along Marine Silk Road involves long distances transportation, so that there is a greater risk of loss, damage or theft of cargo than in domestic trade. Transport risks can be covered by commercial insurance. Meanwhile, export credit insurance is also needed to cover the credit risks of the buyer. In many countries, government-backed export support agencies provide export credit insurance, especially in cases where commercial insurance may not be available. [37]. Thus, in order to promote international trade along Marine Silk Road, the countries involved need to strengthen government-backed export credit insurance.

\subsection{Sociopolitical Risk}

The "One Belt and One Road" initiative is faced with severe challenges in the cultural field. The complex cultural ecology of the countries along the Belt and Road, the ethnocentrism nourished by tradition, and the nationalism trend triggered by the rise of great powers aggravate the cultural conflicts between China and other countries to varying degrees [5]. At present, the marine territorial 
disputes between countries still exist, and the conflicts are further aggravated by the contention for the marine strategic passage. According to the statistics of the piracy reporting center of the International Marine Bureau, from 2000 to 2010, there were 362 criminal cases of armed robbery at sea in the Strait of Malacca [38]. The Marine Silk Road requires countries to consider the interests of other countries when formulating their own security policies, which are also important impediments to maintaining an orderly navigation environment and the development of the Marine Silk Road [39].

\subsubsection{Strengthen the Construction and the Cooperation of Navel Military Forces}

Along with the development of Marine Silk Road, the waters of the countries involved have divergent interests, and each country is strengthening the naval military power [40]. This is necessary for the safe navigation of ships. However, cooperation between the navies of each country is necessary to prevent maritime disputes between the countries involved and support the sustainable development of the world [41].

\subsubsection{Strengthen International Exchanges and Cooperation}

The interests of every country are closely related to the interests of other countries. It is difficult for every country to have national interests that do not include the interests of other countries, and the realization of national interests cannot be achieved without cooperation with other countries [42]. As for international issues, one country's unilateral actions do not solve any issues, but can only affect other countries' actions. In other words, without the cooperation of many countries, international issues cannot be resolved. Therefore, without the cooperation of the countries involved, the natural environment of the sea cannot be improved, nor can it bring about the development of the Marine Silk Road [43]. Both economic ties and security interactions are organized at the international level, so international cooperation has become one of the important features of the stable development of the Marine Silk Road [44].

\subsubsection{Improve the International Legal System for the Law of the Sea}

Countries can benefit from mutually beneficial development by developing detailed legal rules for naval operations in peacetime, strengthening the effectiveness of the convention on the law of the sea in regular training, and enhancing political mutual trust to achieve meaningful security cooperation [40]. When conducting trade activities, all countries must follow the rule of WTO and its trade agreements, and follow the organizational and institutionalized management of international trade activities [33]. In addition, to strengthen the integration of marine environmental systems of various countries with international marine environmental systems is also an international trend of increasing unification and convergence between international environmental legislation and domestic legislation [45].

\subsubsection{Raise Public Awareness of Marine Conservation}

In the era of globalization, the society puts forward new requirements and expectations for education. Civic education should go beyond the consideration of a single country, make the public realize that they are both citizens of their own country and citizens of the world, and improve the public's sense of international responsibility [6]. The public of all countries can realize that the importance of the environment to the shipping industry necessitates the effective implementation of national government policies [46]. In addition, strengthening the popularization of marine emergency science and improving the public's ability to deal with marine emergencies is also an indispensable link in promoting the stable development of the Marine Silk Road [14].

By reviewing and sorting out the literature, we have summarized 19 smart prevention methods for Marine Silk Road risks, as shown in Table 2. 
Table 2. Marine Silk Road risk smart prevention system.

\begin{tabular}{|c|c|c|}
\hline & Risk Prevention Methods & Method Description \\
\hline $\mathrm{C} 1$ & Build an intelligent disaster warning system & $\begin{array}{l}\text { strengthen our monitoring, forecasting and early warning capabilities to guard } \\
\text { against the risks of marine natural disasters. }\end{array}$ \\
\hline $\mathrm{C} 2$ & Build an intelligent disaster information sharing platform & $\begin{array}{l}\text { International sharing of marine information can effectively help countries avoid } \\
\text { marine disaster risks. }\end{array}$ \\
\hline $\mathrm{C} 3$ & Training professional and technical personnel in marine meteorology & Marine professionals can effectively capture and analyze marine information. \\
\hline $\mathrm{C} 4$ & Accelerate the development of clean energy for ships & $\begin{array}{l}\text { Promoting the development and dissemination of clean technologies could } \\
\text { benefit the shipping sector. }\end{array}$ \\
\hline $\mathrm{C} 5$ & Build natural barriers for Marine life & Mitigate the damage caused by coastal and marine disasters. \\
\hline C6 & $\begin{array}{l}\text { Promote the development of smart marine pollution monitoring and } \\
\text { control technology }\end{array}$ & Effective prevention of marine pollution caused by shipping. \\
\hline $\mathrm{C} 7$ & Intelligent optimization of marine pollution control methods & $\begin{array}{l}\text { Intelligent management of marine pollution generated by shipping to reduce } \\
\text { the cost of pollution. }\end{array}$ \\
\hline $\mathrm{C} 8$ & Promote the intelligent ship & Effectively ensure the safety of navigation. \\
\hline C9 & Use big data technology to monitor ocean passages & $\begin{array}{l}\text { Reasonable arrangement of international shipping time to avoid traffic } \\
\text { congestion and marine traffic accidents. }\end{array}$ \\
\hline $\mathrm{C} 10$ & Standardized and automated ship navigation operation & Reduce the possibility of marine traffic accidents. \\
\hline $\mathrm{C} 11$ & Promote the development of smart ports & $\begin{array}{l}\text { Give full play to the important role of ports in preventing coastal and } \\
\text { marine disasters. }\end{array}$ \\
\hline $\mathrm{C} 12$ & Improve the international trade finance system & Reduce the adverse effect of international fraud on international trade. \\
\hline $\mathrm{C} 13$ & Promoting the development of financial derivatives & Avoid the exchange rate fluctuation in the international financial transactions. \\
\hline $\mathrm{C} 14$ & Establish an investment risk assessment system & $\begin{array}{l}\text { Improve overseas investment information database, assist enterprises to reduce } \\
\text { the risk of investment. }\end{array}$ \\
\hline $\mathrm{C} 15$ & Establish and improve the insurance system & Stronger insurance schemes can reduce the vulnerability of international trade \\
\hline $\mathrm{C} 16$ & $\begin{array}{l}\text { Strengthen the construction and the cooperation of marine } \\
\text { military forces }\end{array}$ & $\begin{array}{l}\text { Reducing international marine conflicts of interest ensures the stability of } \\
\text { economic exchanges. }\end{array}$ \\
\hline $\mathrm{C} 17$ & Strengthen international exchanges and cooperation & Promote economic exchanges and provide mutually beneficial cooperation. \\
\hline $\mathrm{C} 18$ & Improve the international legal system for the law of the sea & $\begin{array}{l}\text { Strengthen international norms of marine conduct, promote political mutual } \\
\text { trust and promote international cooperation. }\end{array}$ \\
\hline C19 & Raise public awareness of marine conservation & $\begin{array}{l}\text { Raise public awareness of the importance and urgency of the marine } \\
\text { environment in the shipping industry. }\end{array}$ \\
\hline
\end{tabular}




\section{Method}

The following research process is designed in this paper. First of all, the research theme is clarified and the risk prevention system of the maritime Silk Road is constructed. Then, we invited experts in related fields to revise the index system and fill in the questionnaire. Next, the calculation results are obtained by exploring the Fuzzy-DEMATEL and ISM models. Finally, a complete intelligent risk prevention system is founded for the maritime Silk Road. The whole process is shown in Figure 1.

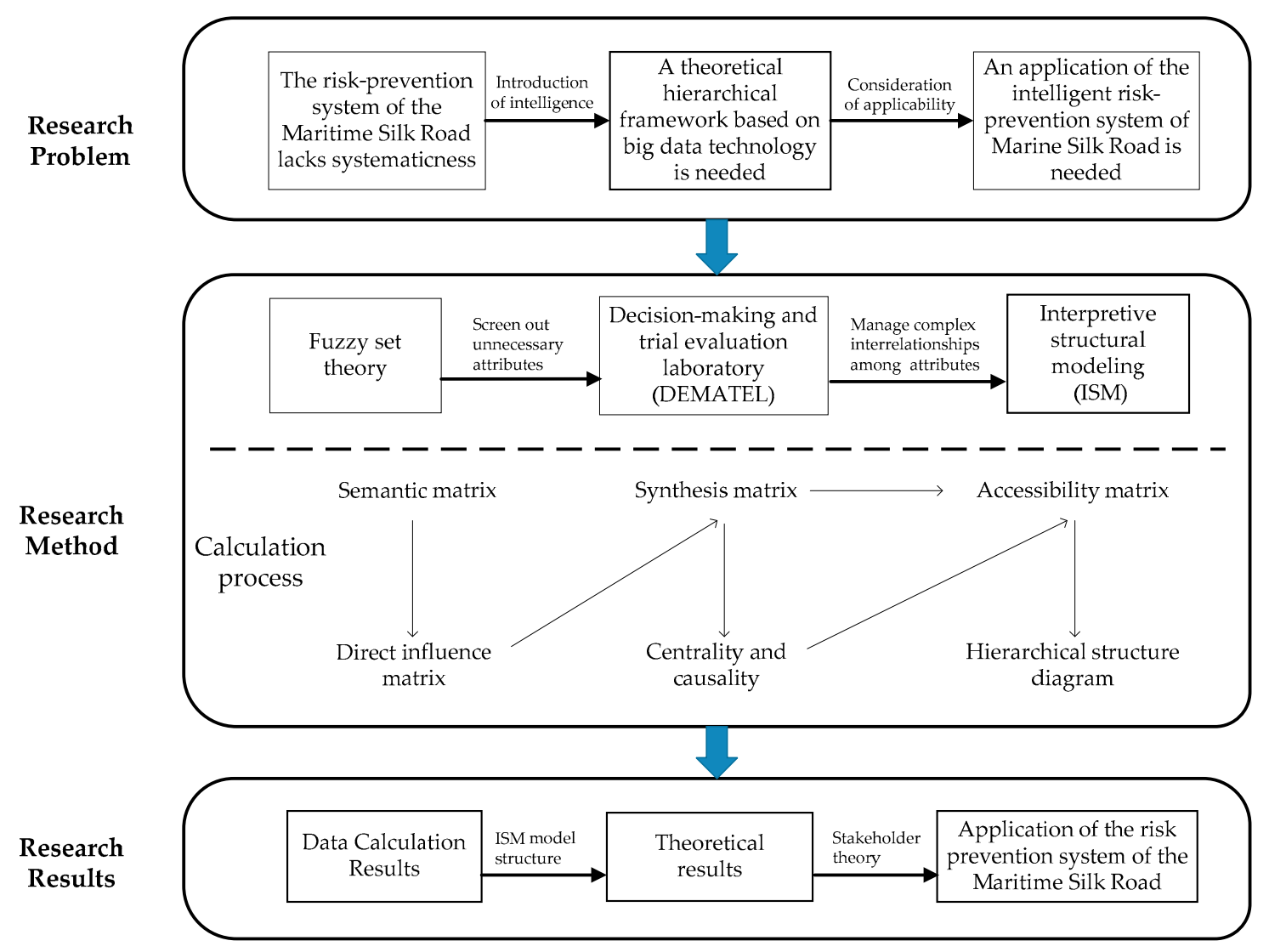

Figure 1. Research design.

\subsection{Fuzzy-DEMATEL}

Fuzzy mathematics is based on the fuzzy set theory, which is applicable to the analysis of the fuzzy degree of correlation between elements. It is a method of processing fuzzy information simulating the human brain. By introducing the fuzzy set theory and the subjective judgment of experts in triangular fuzzy number, it can eliminate the subjectivity of experts' scoring [47].

Fuzzy-DEMATEL method can not only retain the advantages of traditional DEMATEL method in factor recognition [48], but also replaces the original accurate value with triangular. Fuzzy number reflect the real situation of the problem more comprehensively. It improves the credibility of the analysis results and provides a reliable reference for managers to make decisions [49]:

Step 1: For the problem under study, established a system of influencing factors set to F1, F2,..., Fn.

Step 2: According to the expert scoring method to determine the influence relationship between the methods, and the matrix form is used to express. Experts were invited to evaluate the relationship between methods using language operators "no influence $(\mathrm{N})$ ", "very weak influence (VL)", "weak influence $(\mathrm{L})$ ", "strong influence $(\mathrm{H})$ ", and "very strong influence $(\mathrm{VH})$ ". The original expert evaluation is converted into triangular fuzzy number by means of semantic table, which represents 
the influence of $\mathrm{i}$ method on $\mathrm{j}$ method according to the KTH expert, as shown in Table 3. Conversion from language variables to triangular fuzzy Numbers:

$$
W_{i j}^{k}=\left(a_{1 i j^{\prime}}^{k} a_{2 i j^{\prime}}^{k}, a_{3 i j}^{k}\right)=\left(\max \left\{\frac{i-1}{n}, 0\right\}, \frac{i}{n}, \min \left\{\frac{i-1}{n}, 1\right\}\right) i \in\{0,1, \cdots n\}
$$

where $\mathrm{k}$ is the kth questionnaire of expert, while $\mathrm{i}$ and $\mathrm{j}$ are the row and column number of the risk prevention method matrix, respectively.

Step 3: The method of converting the Fuzzy data into crips scores (CFCS) is used to defuzzify the initial values of the expert scores, as the nth order directly affects the matrix $\mathrm{Z}$, and the direct influence matrix reflects the direct effect between the factors, including the following four steps:

- Normalize triangular fuzzy numbers:

$$
\begin{aligned}
x a_{1 i j}^{k} & =\left(a_{1 i j}^{k}-\min a_{1 i j}^{k}\right) / \Delta_{\min }^{\max } \\
x a_{2 i j}^{k} & =\left(a_{2 i j}^{k}-\min a_{1 i j}^{k}\right) / \Delta_{\min }^{\max } \\
x a_{3 i j}^{k} & =\left(a_{3 i j}^{k}-\min a_{1 i j}^{k}\right) / \Delta_{\min }^{\max }
\end{aligned}
$$

Among them, $\Delta_{\min }^{\max }=\max a_{3 i j}^{k}-\min a_{1 i j^{\prime}}^{k}$ In turn, we can calculate $x a_{1 i j^{\prime}}^{k} x a_{2 i j^{\prime}}^{k} x a_{3 i j^{k}}^{k}$.

- Standardize left and right values:

$$
\begin{aligned}
& x l s_{i j}^{k}=x a_{2 i j}^{k} /\left(1+x a_{2 i j}^{k}-x a_{1 i j}^{k}\right) \\
& x r s_{i j}^{k}=x a_{3 i j}^{k} /\left(1+x a_{3 i j}^{k}-x a_{2 i j}^{k}\right)
\end{aligned}
$$

- Calculate the clear value after defuzzification:

$$
\begin{gathered}
x_{i j}^{k}=\left[x l s_{i j}^{k}\left(1-x l s_{i j}^{k}\right)+x r s_{i j}^{k} x r s_{i j}^{k}\right] /\left[1-x l s_{i j}^{k}+x r s_{i j}^{k}\right] \\
z_{i j}^{k}=\min a_{1 i j}^{k}+x_{i j}^{k} \times \Delta_{\min }^{\max }
\end{gathered}
$$

- Calculate the average clear value:

$$
z_{i j}=\left(z_{i j}^{1}+z_{i j}^{2}+\cdots+z_{i j}^{k}\right) / n
$$

Step 4: The direct influence matrix $\mathrm{Z}$ is standardized, and then the normalized direct influence matrix $\mathrm{G}$ is obtained:

$$
\lambda=1 / \max _{1 \leq \mathrm{i} \leq \mathrm{n}} \sum_{j=1}^{n} z_{i j}, \mathrm{G}=\lambda \mathrm{Z}
$$

Step 5: The synthesis matrix $\mathrm{T}$ is calculated according to the following formula: $\mathrm{T}=G+G^{2}+\cdots G^{n}$ or $\mathrm{T}=(E+G)^{-1} \mathrm{E}$ is the identity matrix.

Step 6: The elements in matrix $\mathrm{T}$ are added by row as the influence degree $\mathrm{Di}$, which represents the comprehensive influence value of the row factor on all other factors. The elements in matrix $\mathrm{T}$ are added as the affected degree Ri by column, indicating the comprehensive influence value of all other factors in that column. The formulas are as follows:

$$
\begin{aligned}
\mathrm{D}_{i} & =\sum_{j=1}^{n} t_{i j}(i=1,2, \cdots, n) \\
\mathrm{R}_{i} & =\sum_{j=1}^{n} t_{i j}(i=1,2, \cdots, n)
\end{aligned}
$$


Sum of the degree of influence and the influence degree on other factors is called centrality $\mathrm{m}_{\mathrm{i}}$, indicating the position of the method in the system and the size of the effect. The difference between the degree of influence and the degree to be influenced is called the degree of cause $\mathrm{n}_{\mathrm{i}}$, which reflects the causal relationship between the influencing methods. If the causality is greater than 0 , the factor has a great effect on other factors and is called the factor of cause. If the causality is less than 0 , the factor is greatly affected by other factors and is called the factor of result. The formulas are as follows:

$$
\begin{aligned}
m_{i} & =D_{i}+R_{i}(i=1,2, \cdots, n) \\
n_{i} & =D_{i}+R_{i}(i=1,2, \cdots, n)
\end{aligned}
$$

Step 7: Based on the above analysis of the importance of each method and the interaction between the methods, for the actual system to put forward policy recommendations.

Table 3. Semantic transformation table.

\begin{tabular}{cc}
\hline Linguistic Variables & Triangular Fuzzy Number (TFN) \\
\hline N (No influence) & $(0,0,0.2)$ \\
VL (Very low influence) & $(0,0.2,0.4)$ \\
L (Low influence) & $(0.2,0.4,0.6)$ \\
H (High influence) & $(0.4,0.6,0.8)$ \\
VH (Very high influence) & $(0.8,1,1)$ \\
\hline
\end{tabular}

\subsection{ISM}

Although DEMATEL method can calculate the importance degree of a specific prevention method in the influencing factor system, it cannot determine the internal correlation of the prevention method and divide the hierarchy, so it is difficult to effectively manage and control the prevention method. Therefore, this paper uses ISM method to classify the system structure. The ISM method can transform fuzzy ideas into intuitive ones with good structural relations, and is suitable for system analysis with many variables, complex relations, and an unclear structure [47].

ISM is a recognized method for identifying relationships between specific elements that define a problem. ISM is a mature qualitative tool, which can be applied to various disciplines. For example, Luthra et al. through the application of ISM, this paper discusses various obstacles of green supply chain management (GSCM) in Indian automobile industry [50]. Talib et al. apply the ISM method to understand the interaction between total quality management (TQM) barriers in an organization [51]. Haleem et al. analyzed the key success factors of world-class manufacturing practices using ISM method [52]. The basic steps to implement ISM are as follows:

1. Calculate the overall influence matrix F. The calculation formula is:

$$
\mathrm{F}=\mathrm{I}+T=\left[f_{i j}\right]_{n \times n}
$$

where, the matrix I is the identity matrix;

2. The threshold is introduced to eliminate redundant information for the most streamlined matrix. According to the trial calculation, the most suitable threshold calculation model is obtained. The calculation formula is:

$$
\lambda=\alpha+\beta
$$

In this equation, $\alpha, \beta$ are the mean and standard deviation of all the elements in $\mathrm{T}$. 
3. According to the overall influence matrix of the system and the threshold value to remove the redundant factors, the reachable matrix $\mathrm{M}$ is obtained.

$$
m_{i j}=\left\{\begin{array}{l}
1, f_{i j} \geq \lambda \\
0, f_{i j}<\lambda
\end{array}(i, j=1,2,3, \cdots, n)\right.
$$

In formula, 1 means there is a direct effect between the two factors, while 0 means there is no direct effect between the two factors.

4. The accessible set and the preceding item set of each factor were determined, and the accessible set $\mathrm{Ri}$ and the preceding item set $\mathrm{Si}$ were obtained by hierarchical processing.

$$
\begin{aligned}
& R i=\left\{a_{j} \mid a_{j} \in A, k_{i j} \neq 0\right\},(i=1, \cdots, m) \\
& S i=\left\{a_{j} \mid a_{j} \in A, k_{i j} \neq 0\right\},(i=1, \cdots, m)
\end{aligned}
$$

5. Check the following. If it is true, it indicates that the corresponding factor is the underlying factor, and then the rows and columns corresponding to the factors are deleted in the matrix $\mathrm{M}$.

$$
\mathrm{R}_{i}=\mathrm{R}_{i} \cap \mathrm{S}_{i}
$$

6. Repeat step 4 and step 5 until you get the factor set $\mathrm{Nq}(\mathrm{q}=1,2, \ldots, \mathrm{n})$ at each level and all factors in the reachable matrix $\mathrm{M}$ are deleted.

7. According to the matrix obtained in step 6, the hierarchical structure diagram of influencing factors is drawn in the order in which the factors are crossed out.

\section{Results}

Based on the review and analysis of literatures, this paper summarizes 19 smart prevention methods of the Marine Silk Road, and we interviewed seven marine experts to get their views on the relationship of the 19 methods by scoring, and then corrected their answers to obtain the fuzzy direct impact matrix. Then, according to the CFCS method, the raw data were processed to determine the direct impact matrix between the smart prevention methods of Marine Silk Road risks, as shown in Table 4.

The direct impact matrix of the Marine Silk Road risk intelligent prevention system is standardized to obtain the standardized direct impact matrix. As shown in Table 5, according to the formula $\mathrm{T}=G(E-G)^{-1}$, the matrix is calculated by Python 3.6, and the comprehensive impact matrix $\mathrm{T}$ can be obtained.

According to Formulas (7) and (8), the influence degree, affected degree, centrality and causality are calculated, as shown in Table 6.

The DEMATEL causality diagram is shown in Figure 2. 
Table 4. Direct Impact Matrix.

\begin{tabular}{|c|c|c|c|c|c|c|c|c|c|c|c|c|c|c|c|c|c|c|c|}
\hline & $\mathrm{C} 1$ & $\mathrm{C} 2$ & C3 & $\mathrm{C} 4$ & C5 & C6 & C7 & $\mathrm{C} 8$ & C9 & C10 & C11 & $\mathrm{C} 12$ & C13 & C14 & C15 & C16 & C17 & C18 & C19 \\
\hline $\mathrm{C} 1$ & 0.000 & 0.340 & 0.209 & 0.209 & 0.209 & 0.279 & 0.320 & 0.279 & 0.049 & 0.209 & 0.279 & 0.019 & 0.340 & 0.049 & 0.059 & 0.059 & 0.019 & 0.009 & 0.320 \\
\hline $\mathrm{C} 2$ & 049 & 0.000 & 0.340 & .340 & 0.340 & 0.099 & 0.219 & 0.029 & 0.019 & 0.340 & 0.029 & 0.229 & 0.169 & 0.019 & 0.009 & 0.039 & 0.239 & 0.219 & 0.179 \\
\hline $\mathrm{C} 3$ & 139 & 0.039 & 0.000 & 0.019 & 0.029 & 0.119 & 0.009 & 0.129 & 0.099 & 0.019 & 0.119 & 0.189 & 0.019 & 0.009 & 0.019 & 0.009 & 0.189 & 0.189 & 0.029 \\
\hline C4 & 029 & 0.039 & 119 & & & & & & & & & & & & & & & & 0.029 \\
\hline C5 & 0. & 0.03 & 0.009 & & 0.00 & 0.0 & 0.0 & 0.02 & & 0.0 & 0.0 & & 0.0 & & 19 & 0.009 & 149 & 49 & 0.039 \\
\hline C6 & 269 & 0.340 & 0.209 & 0.209 & 0.209 & 0.000 & 0.340 & 0.289 & 0.049 & 0.209 & 0.289 & 0.019 & 0.340 & 0.049 & 0.049 & 0.049 & 0.019 & 0.009 & 0.340 \\
\hline C7 & 0.029 & 0.179 & 0.340 & 0.340 & 0.340 & 0.099 & 0.000 & 0.079 & 0.019 & 0.340 & 0.029 & 0.219 & 0.179 & 0.029 & 0.019 & 0.019 & 0.249 & 0.249 & 0.179 \\
\hline C8 & 0.289 & 0.340 & 0.209 & 0.209 & 0.209 & 0.279 & 0.310 & 0.000 & 0.039 & 0.209 & 0.259 & 0.009 & 0.340 & 0.039 & 0.049 & 0.049 & 0.019 & 0.009 & 0.340 \\
\hline C9 & 0.340 & 0.209 & 0.089 & 0.059 & 0.059 & 0.340 & 0.209 & 0.340 & 0.000 & 0.099 & 0.340 & 0.029 & 0.209 & 0.340 & 0.320 & 0.340 & 0.069 & 0.069 & 0.209 \\
\hline C10 & 0.019 & 0.029 & 0.009 & 0.009 & 0.009 & 0.019 & 0.039 & 0.059 & 0.019 & 0.000 & 0.019 & 0.149 & 0.039 & 0.029 & 0.029 & 0.019 & 0.149 & 0.059 & 0.039 \\
\hline C11 & 0.320 & 0.320 & 0.219 & 0.219 & 0.219 & 0.299 & 0.340 & 0.279 & 0.049 & 0.219 & 0.000 & 0.039 & 0.320 & 0.049 & 0.039 & 0.059 & 0.039 & 0.039 & 0.340 \\
\hline $\mathrm{C} 12$ & 0.129 & 0.109 & 0.259 & 0.229 & 0.279 & 0.199 & 0.129 & 0.199 & & 0.299 & 0.229 & & & & & 0.340 & 0.340 & & 0.129 \\
\hline C13 & & & & & & & & & & & & & & & & 0.009 & & & 0.320 \\
\hline C14 & 0.289 & 0.149 & 0.029 & 0.039 & 0.039 & 0.289 & 0.179 & 0.289 & 0.299 & 0.039 & 0.310 & 0.019 & 0.199 & 0.000 & 0.279 & 0.299 & 0.019 & 0.019 & 0.209 \\
\hline C15 & 0.340 & 0.189 & 0.039 & 0.029 & 0.049 & 0.340 & 0.199 & 0.340 & 0.310 & 0.039 & 0.340 & 0.019 & 0.209 & 0.310 & 0.000 & 0.310 & 0.019 & 0.019 & 0.209 \\
\hline C16 & 0.340 & 0.189 & 0.059 & 0.069 & 0.049 & 0.340 & 0.189 & 0.340 & 0.340 & 0.119 & 0.340 & 0.019 & 0.209 & 0.340 & 0.340 & 0.000 & 0.009 & 0.029 & 0.199 \\
\hline C17 & 0.169 & 0.159 & 0.289 & 0.289 & 0.289 & 0.209 & 0.179 & 0.199 & 0.299 & 0.340 & 0.199 & 0.360 & 0.149 & 0.279 & 0.239 & 0.279 & 0.000 & 0.299 & 0.169 \\
\hline C18 & 0.149 & 0.129 & 0.289 & 0.310 & 0.310 & 0.199 & 0.149 & 0.209 & 0.279 & 0.340 & 0.199 & 0.340 & 0.169 & 0.279 & 0.279 & 0.279 & 0.320 & 0.000 & 0.159 \\
\hline C19 & 0.069 & 0.109 & 0.310 & 0.310 & 0.310 & 0.029 & 0.139 & 0.029 & 0.039 & 0.340 & 0.069 & 0.229 & 0.139 & 0.049 & 0.069 & 0.069 & 0.229 & 0.229 & 0.000 \\
\hline
\end{tabular}


Table 5. The aggregate impact matrix $\mathrm{T}$.

\begin{tabular}{|c|c|c|c|c|c|c|c|c|c|c|c|c|c|c|c|c|c|c|}
\hline & $\mathrm{C} 1$ & $\mathrm{C} 2$ & $\mathrm{C} 3$ & $\mathrm{C} 4$ & C6 & C7 & $\mathrm{C} 8$ & C9 & C10 & C11 & $\mathrm{C} 12$ & C13 & C14 & C15 & C16 & $\mathrm{C} 17$ & C18 & C19 \\
\hline C1 & 0.053 & 0.138 & 0.120 & 0.117 & 0.120 & 0.116 & 0.136 & 0.114 & 0.046 & 0.124 & 0.113 & 0.060 & 0.141 & 0.050 & 0.049 & 0.046 & 0.062 & 0.055 \\
\hline $\mathrm{C} 2$ & 0.056 & 0.049 & 0.135 & 0.133 & 0.137 & 0.070 & 0.098 & 0.056 & 0.046 & 0.141 & 0.055 & 0.106 & 0.089 & 0.047 & 0.043 & 0.047 & 0.108 & 0.099 \\
\hline C3 & 0.065 & 0.047 & 0.041 & 0.044 & 0.048 & 0.064 & 0.041 & 0.066 & 0.049 & 0.048 & 0.063 & 0.071 & 0.044 & 0.032 & 0.032 & 0.030 & 0.071 & 0.069 \\
\hline C4 & 0.029 & 0.032 & 0.053 & 0.026 & 0.054 & 0.027 & 0.028 & 0.027 & 0.024 & 0.056 & 0.031 & 0.056 & 0.033 & 0.026 & 0.035 & 0.024 & 0.056 & 0.052 \\
\hline C5 & 0.021 & 0.029 & 0.026 & 0.028 & 0.025 & 0.025 & 0.030 & 0.027 & 0.023 & 0.031 & 0.025 & 0.052 & 0.030 & 0.024 & 0.022 & 0.020 & 0.053 & 0.051 \\
\hline C6 & 0.111 & 0.139 & 0.121 & 0.118 & 0.121 & 0.056 & 0.140 & 0.116 & 0.046 & 0.125 & 0.115 & 0.061 & 0.141 & 0.050 & 0.047 & 0.044 & 0.063 & 0.055 \\
\hline C7 & 0.053 & 0.089 & 0.136 & 0.134 & 0.138 & 0.071 & 0.052 & 0.067 & 0.046 & 0.142 & 0.056 & 0.104 & 0.092 & 0.050 & 0.046 & 0.044 & 0.111 & 0.106 \\
\hline C8 & 0.113 & 0.137 & 0.118 & 0.116 & 0.119 & 0.114 & 0.132 & 0.053 & 0.043 & 0.123 & 0.107 & 0.057 & 0.139 & 0.046 & 0.046 & 0.043 & 0.061 & 0.054 \\
\hline C9 & 0.158 & 0.138 & 0.109 & 0.101 & 0.103 & 0.162 & 0.140 & 0.160 & 0.057 & 0.117 & 0.159 & 0.066 & 0.143 & 0.133 & 0.125 & 0.127 & 0.076 & 0.071 \\
\hline C10 & 0.023 & 0.026 & 0.024 & 0.024 & 0.025 & 0.024 & 0.029 & 0.032 & 0.021 & 0.024 & 0.024 & 0.050 & 0.029 & 0.024 & 0.023 & 0.020 & 0.050 & 0.030 \\
\hline C11 & 0.124 & 0.137 & 0.126 & 0.123 & 0.127 & 0.123 & 0.143 & 0.118 & 0.049 & 0.130 & 0.057 & 0.067 & 0.140 & 0.052 & 0.048 & 0.049 & 0.069 & 0.064 \\
\hline $\mathrm{C} 12$ & 0.129 & 0.124 & 0.157 & 0.147 & 0.162 & 0.148 & 0.132 & 0.147 & 0.155 & 0.174 & 0.152 & 0.077 & 0.139 & 0.158 & 0.150 & 0.148 & 0.151 & 0.144 \\
\hline $\mathrm{C} 13$ & 0.043 & 0.076 & 0.086 & 0.089 & 0.087 & 0.045 & 0.078 & 0.045 & 0.047 & 0.091 & 0.045 & 0.079 & 0.045 & 0.082 & 0.060 & 0.038 & 0.086 & 0.072 \\
\hline C14 & 0.135 & 0.112 & 0.082 & 0.082 & 0.084 & 0.137 & 0.120 & 0.136 & 0.110 & 0.089 & 0.139 & 0.052 & 0.126 & 0.051 & 0.108 & 0.109 & 0.055 & 0.050 \\
\hline C15 & 0.152 & 0.128 & 0.092 & 0.088 & 0.094 & 0.154 & 0.132 & 0.153 & 0.116 & 0.097 & 0.152 & 0.057 & 0.136 & 0.121 & 0.052 & 0.115 & 0.059 & 0.055 \\
\hline C16 & 0.155 & 0.131 & 0.098 & 0.098 & 0.096 & 0.158 & 0.133 & 0.156 & 0.125 & 0.116 & 0.155 & 0.059 & 0.139 & 0.130 & 0.126 & 0.052 & 0.060 & 0.059 \\
\hline C17 & 0.130 & 0.130 & 0.162 & 0.158 & 0.163 & 0.143 & 0.137 & 0.141 & 0.137 & 0.181 & 0.140 & 0.153 & 0.134 & 0.137 & 0.125 & 0.130 & 0.080 & 0.137 \\
\hline C18 & 0.125 & 0.123 & 0.161 & 0.161 & 0.166 & 0.141 & 0.130 & 0.142 & 0.133 & 0.180 & 0.139 & 0.149 & 0.137 & 0.137 & 0.133 & 0.130 & 0.147 & 0.072 \\
\hline C19 & 0.062 & 0.073 & 0.126 & 0.123 & 0.127 & 0.057 & 0.081 & 0.057 & 0.051 & 0.138 & 0.064 & 0.102 & 0.082 & 0.054 & 0.056 & 0.054 & 0.103 & 0.098 \\
\hline
\end{tabular}




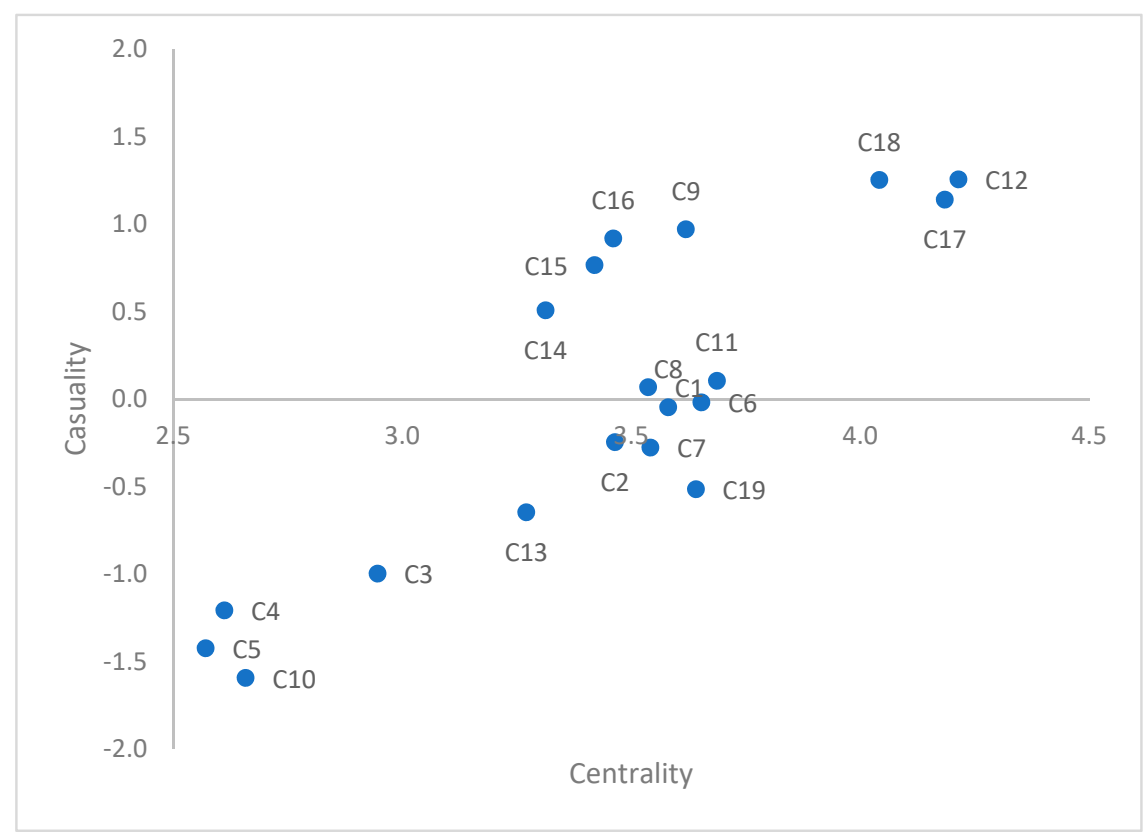

Figure 2. Decision-making and trial evaluation laboratory (DEMATEL) causal diagram.

Table 6. Comprehensive impact matrix analysis.

\begin{tabular}{ccccc}
\hline $\begin{array}{c}\text { Decision-Making and Trial } \\
\text { Evaluation Laboratory (DEMATEL) }\end{array}$ & $\begin{array}{c}\text { Influence } \\
\text { Degree (D) }\end{array}$ & $\begin{array}{c}\text { Affected } \\
\text { Degree (R) }\end{array}$ & $\begin{array}{c}\text { Centrality } \\
\text { (m) }\end{array}$ & $\begin{array}{c}\text { Causality } \\
\text { (n) }\end{array}$ \\
\hline C1 & 1.802 & 1.735 & 3.537 & 0.068 \\
C2 & 1.609 & 1.855 & 3.465 & -0.246 \\
C3 & 0.974 & 1.973 & 2.946 & -0.999 \\
C4 & 0.701 & 1.910 & 2.612 & -1.209 \\
C5 & 0.573 & 1.998 & 2.571 & -1.425 \\
C6 & 1.817 & 1.836 & 3.653 & -0.019 \\
C7 & 1.632 & 1.910 & 3.542 & -0.278 \\
C8 & 1.767 & 1.814 & 3.581 & -0.047 \\
C9 & 2.295 & 1.325 & 3.619 & 0.970 \\
C10 & 0.532 & 2.127 & 2.658 & -1.595 \\
C11 & 1.896 & 1.791 & 3.687 & 0.104 \\
C12 & 2.735 & 1.479 & 4.215 & 1.256 \\
C13 135 & 1.959 & 3.271 & -0.648 \\
C14 & 1.312 & 1.403 & 3.313 & 0.507 \\
C15 & 1.910 & 1.327 & 3.420 & 0.766 \\
C16 & 2.093 & 1.271 & 3.461 & 0.918 \\
C17 & 2.190 & 1.522 & 4.185 & 1.140 \\
C18 & 2.662 & 1.395 & 4.042 & 1.253 \\
C19 & 2.647 & 2.078 & 3.641 & -0.515 \\
\hline
\end{tabular}

For this reason, 19 preventive methods are divided into the cause set and the result set. Table 5 shows 10 methods, including disaster monitoring and early warning system of intelligent information construction (C1), promote the development of marine pollution monitoring technology wisdom (C6), use big data technology to real-time monitor the sea channel situation (C9), promote the wisdom of port construction (C11), perfect the credit system of international trade (C12), set up investment risk assessment system (C14), establishing and perfecting the insurance system (C15), to strengthen the construction of marine military power (C16), strengthen international exchanges and cooperation and (C17), and establish a perfect legal system of international marine law (C18). Among them, the corresponding influence degree of $\mathrm{C} 12, \mathrm{C} 17$, and $\mathrm{C} 18$ is $2.4523,2.5244$, and 2.5247 respectively, which are the three factors with the highest influence degree among all factors. This is because the sustainable development of the Marine 
Silk Road cannot be separated from international cooperation and the standardization of international trade. International exchanges, cooperation, and a sound international marine legal system are important guarantees to ensure the stability of international trade. Therefore, the establishment of the Marine Silk Road risk intelligent prevention system should focus on this consideration.

Nine results include an intelligent information sharing platform construction of disaster (C2), marine climate professional and technical personnel training (C3), accelerating the development of ship power clean energy (C4), construction of marine natural barrier (C5), promote the intelligent marine pollution control method (C7), promote the development of ship intelligent (C8), standardization of ship operation (C10), promote the development of financial derivatives (C13), and raise the public awareness of marine conservation (C19). These methods have a weak impact on risk prevention of the Marine Silk Road, but they are more likely to be affected by other factors and change. Therefore, appropriate attention and control should be paid to the actual management to help improve the prevention effect.

According to the order of centrality, the factors are $\mathrm{C} 17, \mathrm{C} 18, \mathrm{C} 12, \mathrm{C} 11, \mathrm{C} 19, \mathrm{C} 9, \mathrm{C} 6, \mathrm{C} 7, \mathrm{C} 16, \mathrm{C} 13$, $\mathrm{C} 8, \mathrm{C} 2, \mathrm{C} 1, \mathrm{C} 15, \mathrm{C} 14, \mathrm{C} 10, \mathrm{C} 3, \mathrm{C} 5$, and C4 from the largest to the smallest.

According to Formula (9), as shown in Table 7, the reach-ability matrix M composed of 0 and 1 is constructed. 1 indicates a strong relationship between the two factors, and 0 indicates no or weak relationship between the two factors. The reachable and antecedent sets of factors of the first-level decomposition structure are shown in Table 8.

It can be seen from Table 7 that the reachable set and the common set intersect with factors $\mathrm{C} 12$, $\mathrm{C} 17$ and $\mathrm{C} 18$, so elements $\mathrm{C} 12, \mathrm{C} 17$, and $\mathrm{C} 18$ constitute the first-level influencing factors. The rows and columns of the influencing factors $\mathrm{C} 12, \mathrm{C} 17$ and $\mathrm{C} 18$ in the matrix M are deleted to obtain a higher-level decomposition matrix, and the above process is repeated. The factor set $\mathrm{Nq}(\mathrm{q}=1,2 \ldots, 5)$ : first-level node $\mathrm{N} 1=\{\mathrm{C} 3, \mathrm{C} 4, \mathrm{C} 5, \mathrm{C} 10, \mathrm{C} 13$,$\} ; Level 2$ node $\mathrm{N} 2=\{\mathrm{C} 2, \mathrm{C} 7, \mathrm{C} 19\} ;$ Level 3 node $\mathrm{N} 3=\{\mathrm{C} 1, \mathrm{C} 6, \mathrm{C} 8$, $\mathrm{C} 11\} ; \mathrm{N} 4=\{\mathrm{C} 9, \mathrm{C} 14, \mathrm{C} 15, \mathrm{C} 16\} ;$ Level 5 node $\mathrm{N} 5=\{\mathrm{C} 12, \mathrm{C} 17, \mathrm{C} 18\}$.

Finally, we can build a hierarchical path from the ISM model for indicators to interact with each other, as shown in Figure 3. The orange arrows represent the same level of interaction. The green arrows show the effect on the upper layers, and the blue arrows show the effect on the cross layers. This provides a complete guide for the intelligent prevention of Marine Silk Road risks.

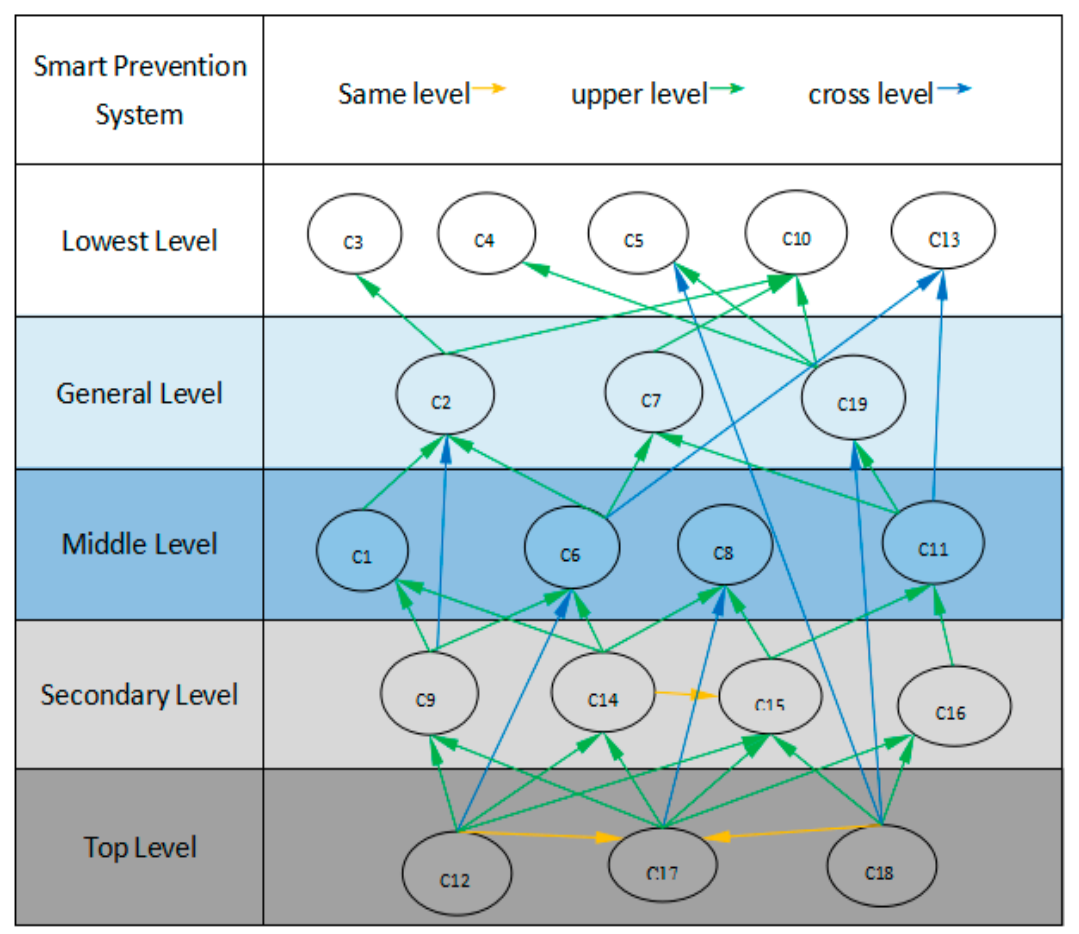

Figure 3. Interpretive structural modeling (ISM) model structure diagram of influencing factors. 
Table 7. Accessibility matrix M.

\begin{tabular}{|c|c|c|c|c|c|c|c|c|c|c|c|c|c|c|c|c|c|c|c|}
\hline & C1 & C2 & C3 & $\mathrm{C} 4$ & C5 & C6 & C7 & C8 & C9 & C10 & C11 & $\mathrm{C} 12$ & $\mathrm{C} 13$ & C14 & C15 & C16 & C17 & C18 & C19 \\
\hline $\mathrm{C} 1$ & 1 & 1 & 0 & 0 & 0 & 0 & 1 & 0 & 0 & 0 & 0 & 0 & 1 & 0 & 0 & 0 & 0 & 0 & 1 \\
\hline $\mathrm{C} 2$ & 0 & 1 & 1 & 0 & 1 & 0 & 0 & 0 & 0 & 1 & 0 & 0 & 0 & 0 & 0 & 0 & 0 & 0 & 0 \\
\hline $\mathrm{C} 3$ & 0 & 0 & 1 & 0 & 0 & 0 & 0 & 0 & 0 & 0 & 0 & 0 & 0 & 0 & 0 & 0 & 0 & 0 & 0 \\
\hline $\mathrm{C} 4$ & 0 & 0 & 0 & 1 & 0 & 0 & 0 & 0 & 0 & 0 & 0 & 0 & 0 & 0 & 0 & 0 & 0 & 0 & 0 \\
\hline C5 & 0 & 0 & 0 & 0 & 1 & 0 & 0 & 0 & 0 & 0 & 0 & 0 & 0 & 0 & 0 & 0 & 0 & 0 & 0 \\
\hline C6 & 0 & 1 & 0 & 0 & 0 & 1 & 1 & 0 & 0 & 0 & 0 & 0 & 1 & 0 & 0 & 0 & 0 & 0 & 1 \\
\hline C7 & 0 & 0 & 1 & 0 & 1 & 0 & 1 & 0 & 0 & 1 & 0 & 0 & 0 & 0 & 0 & 0 & 0 & 0 & 0 \\
\hline C8 & 0 & 1 & 0 & 0 & 0 & 0 & 0 & 1 & 0 & 0 & 0 & 0 & 1 & 0 & 0 & 0 & 0 & 0 & 1 \\
\hline C9 & 1 & 1 & 0 & 0 & 0 & 1 & 1 & 1 & 1 & 0 & 1 & 0 & 1 & 0 & 0 & 0 & 0 & 0 & 1 \\
\hline C10 & 0 & 0 & 0 & 0 & 0 & 0 & 0 & 0 & 0 & 1 & 0 & 0 & 0 & 0 & 0 & 0 & 0 & 0 & 0 \\
\hline C11 & 0 & 1 & 0 & 0 & 0 & 0 & 1 & 0 & 0 & 0 & 1 & 0 & 1 & 0 & 0 & 0 & 0 & 0 & 1 \\
\hline C12 & 0 & 0 & 1 & 1 & 1 & 1 & 0 & 1 & 1 & 1 & 1 & 1 & 1 & 1 & 1 & 1 & 1 & 1 & 1 \\
\hline C13 & 0 & 0 & 0 & 0 & 0 & 0 & 0 & 0 & 0 & 0 & 0 & 0 & 1 & 0 & 0 & 0 & 0 & 0 & 0 \\
\hline C14 & 0 & 0 & 0 & 0 & 0 & 1 & 0 & 1 & 0 & 0 & 1 & 0 & 0 & 1 & 0 & 0 & 0 & 0 & 0 \\
\hline C15 & 1 & 0 & 0 & 0 & 0 & 1 & 0 & 1 & 0 & 0 & 1 & 0 & 1 & 0 & 1 & 0 & 0 & 0 & 1 \\
\hline C16 & 1 & 0 & 0 & 0 & 0 & 1 & 0 & 1 & 0 & 0 & 1 & 0 & 1 & 0 & 0 & 1 & 0 & 0 & 1 \\
\hline C17 & 0 & 0 & 1 & 1 & 1 & 1 & 1 & 1 & 1 & 1 & 1 & 1 & 0 & 1 & 0 & 0 & 1 & 1 & 1 \\
\hline C18 & 0 & 0 & 1 & 1 & 1 & 1 & 0 & 1 & 0 & 1 & 1 & 1 & 1 & 1 & 0 & 0 & 1 & 1 & 1 \\
\hline C19 & 0 & 0 & 0 & 0 & 0 & 0 & 0 & 0 & 0 & 1 & 0 & 0 & 0 & 0 & 0 & 0 & 0 & 0 & 1 \\
\hline
\end{tabular}


Table 8. First-level decomposition structure.

\begin{tabular}{cccc}
\hline $\mathbf{i}$ & $\mathbf{L}\left(f_{i}\right)$ & $\mathbf{P}\left(f_{i}\right)$ & $\mathbf{C}\left(f_{i}\right)=\mathbf{L}\left(f_{i}\right) \cap \mathbf{P}\left(f_{i}\right)$ \\
\hline C1 & $1,2,7,13,19$ & $1,9,15,16$ & 1 \\
C2 & $2,3,5,10$ & $1,2,6,8,9,11$ & 2 \\
C3 & 3 & $2,3,7,12,17,18$ & 3 \\
C4 & 4 & $4,12,17,18$ & 4 \\
C5 & 5 & $2,5,7,12,17,18$ & 5 \\
C6 & $2,6,7,13,19$ & $6,9,12,14,15,16,17,18$ & 6 \\
C7 & $3,5,7,10$ & $1,6,7,9,11,17$ & 7 \\
C8 & $2,8,13,19$ & $8,9,12,14,15,16,17,18$ & 8 \\
C9 & $1,2,6,7,8,9,11,13,19$ & $9,12,17$ & 9 \\
C10 & 10 & $2,7,10,12,17,18,19$ & 10 \\
C11 & $2,7,11,13,19$ & $9,11,12,14,15,16,17,18$ & 11 \\
C12 & $3,4,5,6,8,9,10,11,12,13,14,15,16,17,18,19$ & $12,17,18$ & $12,17,18$ \\
C13 & 13 & $1,6,8,9,11,12,13,15,16,18$ & 13 \\
C14 & $6,8,11,14$ & $12,14,17,18$ & 14 \\
C15 & $1,6,8,11,13,15,19$ & 12,15 & 15 \\
C16 & $1,6,8,11,13,16,19$ & 12,16 & 16 \\
C17 & $3,4,5,6,7,8,9,10,11,12,14,17,18,19$ & $12,17,18$ & $12,17,18$ \\
C18 & $3,4,5,6,8,10,11,12,13,14,17,18,19$ & $12,17,18$ & $12,17,18$ \\
C19 & 10,19 & $1,6,8,9,11,12,15,16,17,18,19$ & 19 \\
\hline
\end{tabular}

According to the ISM model analysis of influencing factors, C12, C17, and C18 are the key to establishing the risk prevention system of the Marine Silk Road.

To sum up, the methods for establishing an intelligent risk prevention system for the Marine Silk Road are very complex, involving the interactions among nature, transportation, economy, society and the international community. The influence mode, influence mechanism, and effect degree of different methods are different, thus forming a systematic integration framework for risk wisdom prevention of the Marine Silk Road.

\section{Discussion}

This paper attempts to establish an intelligent prevention system for Marine Silk Road risks. At present, there are relatively few studies on risk prevention of Marine Silk Road, and no systematic and comprehensive overall system has been provided. This study systematically analyzes the risks that may exist in the development of Marine Silk Road, and according to these risks, integrates the traditional prevention methods and the wisdom methods to sort out 19 risk prevention methods, which are included in the structured hierarchical model. In addition, with the help of the Fuzzy-DEMATEL and ISM methods, the importance and relationship of these prevention methods are analyzed. According to the above data processing process, the results in Table 9 are obtained in this paper. The second column of the table lists the data processing results, and the third column of the table shows the policy implications obtained through the analysis of the data processing results. 
Table 9. Main results.

\begin{tabular}{cll}
\hline & \multicolumn{1}{c}{ Data Calculation Results } & \multicolumn{1}{c}{ Theoretical Results } \\
\hline 1 & $\begin{array}{l}\text { C12, C17, C18 are in the first level of ISM model and have } \\
\text { the highest degree of centrality }\end{array}$ & $\begin{array}{l}\text { The primary task of risk prevention in Marine Silk Road is to ensure } \\
\text { international political security and avoid international trade risks }\end{array}$ \\
\hline 3 & C9, C14, C15, C16 are in the second layer of the ISM model & $\begin{array}{l}\text { Scientific and accurate evaluation of the project is the starting point of } \\
\text { venture capital investment, and reasonable risk diversification through the } \\
\text { insurance system is an important means for enterprises to reduce risks. }\end{array}$ \\
\hline 4 & $\begin{array}{l}\text { C1, C6, C8, C11 are in the intermediate level of the ISM } \\
\text { model, and they are under the influence of international } \\
\text { politics and economy }\end{array}$ & $\begin{array}{l}\text { It is difficult for a single country to solve the problem of maritime traffic } \\
\text { safety. The problems must be solved by all countries in a community } \\
\text { through consultation }\end{array}$ \\
\hline C2, C7, C19 are in the second-to-last level of the ISM model. & $\begin{array}{l}\text { Marine environmental risk prevention will be affected by economy, } \\
\text { international environment and international cooperation }\end{array}$ \\
\hline 5 & $\begin{array}{l}\text { On the basis of stable international environment and close international } \\
\text { economic cooperation, it will take a long time to realize intelligent } \\
\text { technological innovation, clean energy development, marine biological } \\
\text { protection and professional personnel training }\end{array}$ \\
\hline & $\begin{array}{l}\text { Based on stakeholder theory, relevant behaviors of } \\
\text { stakeholders in the marine Silk Road are obtained }\end{array}$ & includes three aspects: international level, government level and firm level \\
\hline
\end{tabular}


First, to improve the international trade finance system (C12), to strengthen international exchanges and cooperation (C17), and to establish and improve the international marine legal system (C18) constitute the first level of ISM model with the highest degree of centrality, which is the primary method to prevent risks of the Marine Silk Road. All of these are important means to solve the international political and economic problems of the Marine Silk Road and all of them are institutional approaches. This top-level system design includes regulating the international legal system and promoting exchanges and cooperation between countries. The establishment of international marine laws and regulations system that coordinates interests of the countries involved can help to converge interest around the world in an interdependent international society, thus forming a community of interests [12]. It will also help the development of the Marine Silk Road, being one of the ways to achieve a "human destiny community" [53]. Building such a human destiny community does not overthrow the national management system, nor does it make a system of "anarchy" of the state of the world. On the premise of mutual respect for state sovereignty, it creates an international cooperation framework, expands the international cultural and economic exchanges and cooperation between countries, brings the standardization of the economic and trade terms, avoids interest conflicts between countries, and promotes national economic reciprocity and mutual benefit, i.e., common development.

Second, to use big data technology to real-time monitor the sea channel situation (C9), to set up investment risk assessment system (C14), to establish and improve the insurance system (C15), and to strengthen the construction and cooperation of marine military power (C16) constitute the second layer of the ISM model. Under the influence of the international political environment, they reflected in the process of Marine Silk Road. The construction and the cooperation of national marine military power create a good external environment for enterprises [54]. The development and improvement of the investment risk assessment system cannot only speed up the flow of venture capital, but also increase the return rate of venture capital and reduce the investment risk of enterprises [55]. Establishing a good insurance system is an urgent requirement and realistic choice for enterprises to achieve sustainable development [56]. In short, the scientific and accurate evaluation of the project is the starting point of venture capital investment, and reasonable risk diversification through the insurance system is an important means for enterprises to reduce risks.

A stable international political environment is a guarantee for countries to take an active part in marine governance. The common development of the international economy is the material basis for marine risk prevention. To establish disaster monitoring and early warning system (C1), to promote the information construction of marine pollution monitoring technology development (C6), to promote the development of intelligent ship (C8), standardization and automation of ship's operation (C11) are in the third level of the ISM model, the four prevention methods are for marine traffic and weather disaster risk, they are under the influence of international politics and economy. The establishment of major international cooperative research programs is of great significance for conducting research on marine disasters across national boundaries and formulating plans for disaster prevention and mitigation [57]. In addition, due to the short period of time to reduce pollutants being unrealistic, there should be money available for the construction of pollution treatment facilities and to establish an ecological pollution treatment system [21], and due to the national economic development levels being different, the protection of the marine ecological environment and construction must be joint efforts. Thus, the international economic governance is the development level of marine material guarantee of the problem.

The construction of an intelligent information sharing platform for disasters (C2), the intelligent optimization of marine pollution control methods (C7), and the intelligent optimization of marine pollution control methods (C19) are at the second-to-last level of the ISM model. These three methods are all prevention methods considering the marine environment. Marine climate disaster prevention is the basic premise of ship navigation, and marine environmental protection is an important guarantee for the sustainable development of the Marine Silk Road [58]. These three methods are also affected by economy, international environment, and international cooperation. Economic and technological 
development can establish a disaster information sharing platform and provide sufficient financial support. A stable international environment and close international cooperation can give full play to the advantages of each country, improve the efficiency of marine environmental protection, and reduce the cost of marine environmental protection [57].

Marine meteorological professional and technical personnel training (C3), accelerating the development of ship power clean energy (C4), construction of marine natural barrier (C5), standardization, automation of ship's operation (C10), and to promote the development of financial derivatives and banking (C13) are in the last level of the ISM model. These four methods continue to be affected by economic factors and social factors comprehensively. At the same time, social, political, and economic development is also affected by the talent energy. The production cost of vessel clean energy is much higher than that of conventional energy [59]. The proportion of fixed assets investment required for ship automation and smart port construction is large and the cost of technology research and development is high, which is easily restricted by the national economic development level. At the same time, the investment, operation and management of equipment assets such as power transmission network in clean energy projects need a stable social and political environment, which is also affected by the international political environment. Meanwhile, the stable development of the financial industry and banking industry also require a stable social environment and economic order [34]. As the effect of public meteorological service are apparent, and the basis of a series of changing environmental services require the participation and support of public meteorological talent, cross-cultural communication is helpful to promote the public meteorological service personnel to quickly absorb the relevant knowledge and applying scientific research to specific business practice, guide the perspective of national scientific research institutes to research into the international field of time, for the development of public meteorological talents with an advanced knowledge base to provide support. In short, it will take a long time to achieve intelligent technology innovation, clean energy development, marine biological protection, and professional personnel training, based on a stable international environment and close international economic cooperation.

In order to understand the theoretical system in this paper, we further develop an application system based on the Marine Silk Road intelligent prevention system. This system, based on the stakeholder theory, carefully designs the relevant behaviors of stakeholders in the Marine Silk Road, as shown in Figure 4.

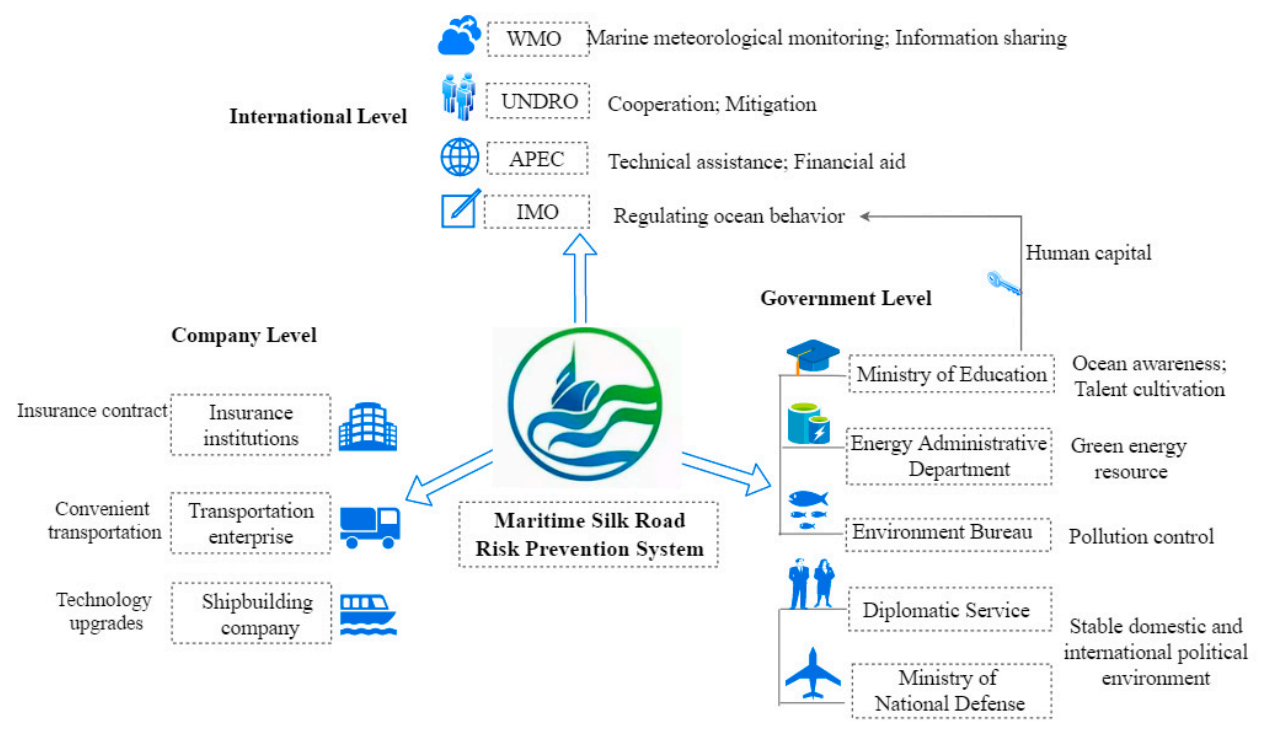

Figure 4. Application of the intelligent risk-prevention system of Marine Silk Road.

The model can be divided into three levels: international level, government level and company level. First, WMO can develop the observation network of the global marine operations project, maintain, 
coordinate and fully integrate the ocean observation system [45]. International cooperation organizations for disaster reduction can launch the "Marine Silk Road" Marine disaster risk assessment and scientifically delimit key marine disaster protection zones [57]. International economic organizations such as APEC could collaborate on projects to provide technical assistance to less able countries [60]. In addition, the International Maritime Organization may issue a license to regulate the marine behavior of states. Second, the levels of government include national ministries of foreign affairs and coastal defense, as well as national environmental agencies, energy control centers and national education departments. The state's foreign affairs and coastal defense departments should formulate a reasonable foreign policy and defense system to provide a stable domestic and international environment for the development of the Marine Silk Road.

The national environment administration and the energy control center can control national pollution emissions and develop new energy based on financial and technical support [59]. At the same time, the education and publicity of national educational institutions can enhance the national awareness of marine protection and provide professional talents for the development of new energy [61]. Finally, countries' financial institutions, transport companies and shipbuilders form the third tier. The production capacity and manufacturing technology of shipbuilding enterprises are the source of ship safety. The improvement of transport capacity is also an important link to ensure the smooth production of shipbuilding enterprises. An insurance institution, as a third party enterprise, may conclude an insurance contract with the enterprise to provide a basis for the settlement of accident disputes and insurance claims.

\section{Conclusions}

To explore an effective risk prevention system for the Marine Silk Road, this paper establishes a hierarchical theoretical framework and explores the application of an intelligent prevention system. However, this hierarchical theoretical framework must exclude unnecessary attributes and consider the interrelationships between the aspects and the criteria. Compared with the previous studies, this article addresses severe climate risks, risks of marine environmental pollution, marine traffic safety risk, financial risk, and social and political risks. This paper not only constructs the intelligent prevention method system of the Marine Silk Road and provides the interaction between methods and hierarchical influence path under the framework, but also develops the application system based on this method system according to the stakeholder theory.

The Fuzzy-DEMATEL-ISM integration method is adopted to analyze the interaction between intelligent risk prevention methods of the Marine Silk Road and determine the intensity of the interaction. Cooperation between countries and the design of top-level legal system are the most important ways to prevent the political risk of the Marine Silk Road. The establishment of a sound insurance system is the premise to obtain comprehensive economic effects. In addition, the use of big data technology is an important way to upgrade the traditional prevention methods. However, various methods, including environmental and ecological protection, play a relatively limited role in risk prevention for the Marine Silk Road, which is affected by international legal norms and the level of economic development. Finally, the application system developed in this paper can provide some behavioral guidance to stakeholders of the Marine Silk Road in a clear and intuitive way.

This article still has some limitations. First, although we have established a system of prevention methods, we cannot avoid the fact that some methods may still be missed and can be further explored and improved upon in the future. Second, the influence relation and degree of indicators are processed and analyzed based on the data provided by experts. Although the fuzzy set theory is used to solve the problem of subjective deviation of experts, there are still errors that are difficult to eliminate completely, which may have a certain impact on the research results. In addition, other statistical tools, such as a structural equation model, can be used in this study to explore more influencing factors and conduct further statistical verification of this model. 
Author Contributions: Writing: X.X. and X.M.; Resource: M.J.; Providing revised advice: Y.G. and S.W.P. All authors have read and agreed to the published version of the manuscript.

Funding: This work is supported by the General program of Humanities and Social Sciences Research of the Ministry of Education of China (19YJC790165), the Liaoning S\&T Project of China (201601054), the Dalian University of Technology Fundamental Research Fund (DUT19RW107).

Conflicts of Interest: The authors declare no conflict of interest.

\section{References}

1. Bao, J.; Li, J.; Gong, C. Marine Shipping and Export Trade on “Marine Silk Road". Asian J. Ship. Logist. 2018, 34, 83-90.

2. Jiang, L.; Jia, Y. Analysis of Topology and Routing Strategy of Container Shipping Network on "Marine Silk Road“. Sustain. Comput.-Infor. 2019, 21, 72-79.

3. Zou, L.; Liu, C.; Yin, G. Spatial Patterns and Economic Effects of China's Trade with Countries along the Belt and Road. Prog. Geogr. 2015, 34, 598-605. (In Chinese)

4. Zhang, X.; Ling, M.; Zhang, Y. A Study of Prevention and Mitigation of Storm Surge Disaster Along Coastal Cities Pertaining to "The Belt and Road Initiative" in China. J. Hohai Univ. 2017, 19, 81-91. (In Chinese)

5. Ross, M.H. The Culture of Conflict: Interpretations and Interests in Comparative Perspective; Yale University Press: New Haven, CT, USA; London, UK, 1993.

6. Alison, L. Sustainable Communities: The Role of Global Citizenship Education. J. Soc. Greek Political Thought 2009, 2, 1-44.

7. Liu, D.; Shi, G.; Li, W. Decision support of collision avoidance based on shortest avoidance distance and collision risk. J. Shanghai Marit. Univ. 2018, 164-169. (In Chinese)

8. Nixon, S.W. Coastal Marine Eutrophication: A Definition, Social Causes, and Future Concerns. Ophelia 1995, 41, 199-219. [CrossRef]

9. Sheu, J. Dynamic Relief-demand Management for Emergency Logistics Operations under Large-scale Disasters. Transp. Res. E-Logist. 2010, 46, 1-17. [CrossRef]

10. He, F.; Zhu, H.; Zhang, Q. Construction of the 21st Century Marine Silk Road: Present Situation, Opportunities, Problems and Solutions. Soc. Sci. 2018, 11, 27-45.

11. Shi, P.; Wang, J.; Xu, W. World Atlas of Natural Disaster Risk; Springer: Berlin/Heidelberg, Germany; Beijing Normal University Press: Beijing, China, 2015; pp. 309-323.

12. Wang, H.; Liu, N.; Zhang, Y.; Yu, T.; Ren, X. Current Situation of Marine and Meteorological Disaster Early Warning Report of "21st Century Marine Silk Road" and Countermeasures for Risk Prevention. Sci. Bull. 2020, 65, 453-462.

13. $\mathrm{Xu}, \mathrm{X}$. "One Belt and One Road" Cooperation in Disaster Prevention and Mitigation: Challenges and Responses. Int. Stud. 2017, 1, 33-44.

14. Carter, W. Disaster Management: A Disaster Manager's Handbook; Asian Development Bank: Manila, Philippines, 1992.

15. Emma, M.; Jepsen, P.J. Pinned Entanglement in Oceanic Plastic Pollution: A Global Review Marine Pollution Bulletin. Mar. Pollut. Bull. 2019, 145, 295-305.

16. Wang, C.; He, S.; Li, Y.; Hou, X.; Yang, C. Current Situation of Marine Oil Spill Pollution and its Ecological Impact in China. Mar. Sci. 2009, 33, 57-60.

17. Feng, Z.; Pang, F.; Wu, H. China's Open Situation of Shipping Service Industry and International Competition Strategy. Railw. ECO Res. 2003, 6, 36-40. (In Chinese)

18. Hara, S.; Terauchi, K.; Koike, I. Abundance of Viruses in Marine Waters: Assessment by Transmission Electron Microscopy. Appl. Environ. Microbiol. 1991, 57, 2731-2734. [CrossRef] [PubMed]

19. Xiao, Y.; Fu, X. Port Investments on Coastal and Marine Disasters Prevention: Economic Modeling and Implications. Transp. Res. B-Meth. 2015, 78, 202-221. [CrossRef]

20. Guan, D.; Zhan, X. Red Tide Disaster in Coastal Waters of China and its Prevention and Control Countermeasures. Mar. Environ. Sci. 2003, 2, 60-63.

21. Wang, M.; Hu, B.; Xin, W.; Qi, L. The Present Situation, Causes and Treatment of Marine Environmental Pollution in China. J. Ocean Univ. China 2006, 5, 1-6. (In Chinese)

22. Zhu, G. The Present Situation and Future Development of Marine Monitoring Technology Research and Development in China. Mar. Technol. 2002, 2, 27-32. (In Chinese) 
23. Hu, S.; Zhang, J. Risk Assessment of Marine Traffic Safety at Coastal Water Area. Procedia Eng. 2012, 45, 31-37. [CrossRef]

24. Wang, Y. Study on Water Traffic Safety in Ningbo-Zhoushan Port Core Port Based on Marine Economic Strategy. China Water Trans. 2013, 13, 38-40. (In Chinese)

25. Siror, J.K.; Huanye, S.; Dong, W. REID Based Model for an Intelligent Port. Comput. Ind. 2011, 62, 795-810. [CrossRef]

26. Jun, M.; Ceesvander, T.; Han, L. Study on Collision Avoidance in Busy Waterways by Using AIS data. Ocean Eng. 2010, 37, 483-490.

27. Fiorini, M.; Capata, A.; Bloisi, D. AIS Data Visualization for Maritime Spatial Planning. Int. J. E-Navig. Marit. Econ. 2016, 5, 45-60. [CrossRef]

28. Kayvan, P.; Neil, F. Investigation on the Impact of Human-automation Interaction in Marine Operations. Ocean Eng. 2018, 153, 297-304.

29. Grinols, E.L.; Perrelli, R. Politics, the WTO and Trade Disputes: Evidence from US Cases. Pac. Econ. Rev. 2002, 7, 335-357. [CrossRef]

30. Rosmawani, C.; Nurul, S. Fraud in Letter of Credit Transactions: The Experience of Malaysian Bankers. Int. J. Law Crime Justice 2014, 42, 224-236.

31. Bac, M.; Raff, H. A Theory of Trade Concessions. J. Int. Econ. 1997, 42, 483-504. [CrossRef]

32. Han, K.-M.; Park, S.-W.; Lee, S. Anti-Fraud in International Supply Chain Finance: Focusing on Moneual Case. J. Korea Trade 2020, 24, 59-81. [CrossRef]

33. Chen, W.; He, C. Game of the Marine Silk Road and Its Economic and Trade Orientation. Reform 2014, 3, 74-83.

34. Yuan, Z. Brief Analysis on the Exchange Rate Risk Management of Multi-National Corporation after the Exchange Rate Reform. Copper Eng. 2007, 1, 16-20.

35. Konstantinos, G.; Athanasios, T. Integration and Risk Contagion in Financial Crises: Evidence from International Stock Markets. J. Bus. Res. 2019, 104, 350-365.

36. Yuan, J.; Li, X.; Xu, C.; Zhao, C.; Liu, Y. Investment Risk Assessment of Coal-fired Power Plants in Countries along the Belt and Road Initiative Based on ANP-Entropy-TODIM Method. Energy 2019, 176, 623-640. [CrossRef]

37. Jimenez, G.C. ICC Guide to Export/Import; ICC Publications: Paris, France, 2012.

38. Karam, W.; Woon, S. Safety Situation of Navigation in the Strait of Malacca. Int. Comp. Law 1998, 2, 491-492.

39. Schuman; Frederick; Kelsen, H. Principles of International Law. Univ. Chic. Law Rev. 1954, 20, 356. [CrossRef]

40. Chang, Y. The "21st Century Marine Silk Road Initiative" and Naval Diplomacy in China. Ocean Coast. Manag. 2018, 153, 148-156. [CrossRef]

41. Wang, Q.; Cui, Y. Introducing Global Governance into the Ocean Field-On the Basic Issues of Global Ocean Governance and China's Coping Strategies. J. Pac. 2015, 23, 17-27.

42. Audrey, O.; Kerry, V. Citizenship and the Challenge of Global Education. Br. J. Educ. Stud. 2004, 52, 91-93.

43. Hoel, M. Global Environmental Problems: The Effects of Unilateral Actions Taken By One Country. J. Environ. Econ. Manag. 1991, 20, 55-70. [CrossRef]

44. Benjamin, M. States, Nations and the Great Powers: The Sources of Regional War and Peace. CUP 2007, 46, 11-20.

45. Liu, Z.; Wang, H. A Preliminary Study on the Interaction between China and the International Marine Environment System. Adv. Clim. Chang. Res. 2015, 6, 118-125. (In Chinese)

46. Han, C. Strategies to Reduce Air Pollution in Shipping Industry. AJSL 2010, 26, 7-29. [CrossRef]

47. Opricovic, S.; Tzeng, G.H. Compromise Solution by MCDM Methods: A Comparative Analysis of VIKOR and TOPSIS. Eur. J. Opera. Res. 2004, 156, 445-455. [CrossRef]

48. Büyüközkan, G.; Çifçi, G. A Novel Hybrid MCDM Approach Based on Fuzzy DEMATEL, Fuzzy ANP and Fuzzy TOPSIS to Evaluate Green Suppliers. Exp. Syst. Appl. 2012, 39, 3000-3011. [CrossRef]

49. Altuntas, S.; Selim, H.; Dereli, T. A fuzzy DEMATEL-Based Solution Approach for Facility Layout Problem: A Case Study. Int. J. Adv. Manuf. Technol. 2014, 73, 749-771. [CrossRef]

50. Lundan, S.M. What Are Ownership Advantages. Multinatl. Bus. Rev. 2010, 18, 51-70. [CrossRef]

51. Talib, F.; Rahman, Z.; Qureshi, M.N. Analysis of Interaction among the Barriers to Total Quality Management Implementation Using Interpretive Structural Modeling Approach. Benchmark. Int. J. 2011, 18, 563-587. [CrossRef] 
52. Haleem, A.; Sushil, Q.M.A.; Kumar, S. Analysis of Critical Success Factors of World-class Manufacturing Practices: An Application of Interpretative Structural Modelling and Interpretative Ranking Process. Prod. Plan. Control 2012, 23, 722-734. [CrossRef]

53. Ben, S. China, Natural Resources, Sovereignty and International Law. Asian Stud. Rev. 2013, 37, $196-214$.

54. Jones, P. Track Two Diplomacy in Theory and Practice; SUP: Loboc, Lalawigan ng Bohol, Philippines, 2015.

55. Diamond, D.; Diybvig, P. Bank Runs, Deposit Insurance, and Liquidity. J. Polit. Econ. 1983, 91, 401-419. [CrossRef]

56. Riding, A.L.; Haines, G. Loan Guarantees: Costs of Default and Benefits to Small Firms. J. Bus. Vent. 2001, 16, 595-612.

57. Giuliani, G.; Peduzzi, P. The Preview Global Risk Data Platform: A Geoportal to Serve and Share Global Data on Risk to Natural Hazards. Nat. Hazards Earth Syst. Sci. 2011, 11, 53-66. [CrossRef]

58. Shi, X.; Liu, S.; Liu, Q.; Tan, J.; Guo, Z. Spatial-temporal Distribution of Storm Surge Damage in the Coastal Areas of China. Nat. Hazards 2015, 79, 237-247. [CrossRef]

59. IEA. Energy Technology Perspectives 2015: Mobilizing Innovation to Accelerate Climate Action. Execu. Summ. 2015, 6 .

60. Hermann, M. The International Society as a Legal Community; Brill Academic Publishers: Leiden, The Netherlands, 1980.

61. Mark, A.; Phillip, C.; Stewart, J. Accumulations of Micro Plastic on Shorelines Worldwide: Sources and Winks. Computer Aided Optimum Design of Structures VIII. Environ. Sci. Technol. 2011, 45, 9175-9179.

(C) 2020 by the authors. Licensee MDPI, Basel, Switzerland. This article is an open access article distributed under the terms and conditions of the Creative Commons Attribution (CC BY) license (http://creativecommons.org/licenses/by/4.0/). 